East African Journal of Science, Technology and Innovation, Vol. 2 (2): March 2021.

This article is licensed under a Creative Commons license, Attribution 4.0 International (CC BY 4.0)

\title{
Utilization of Sugarcane Bagasse Ash from Power Co-generation Boilers as a Supplementary Cementitious Material
}

\author{
1BISASO E., 2BAZAIRWE A., ${ }^{3 *}$ AINOMUGISHA S.
}

\begin{abstract}
${ }^{1}$ Researcher, Department of Lands and Architectural studies, Faculty of Engineering, Kyambogo University Uganda ${ }^{2}$ Assistant Lecturer, Department of Lands and Architectural studies, Faculty of Engineering, Kyambogo University Uganda ${ }^{3}$ Assistant Lecturer, Department of Lands and Architectural studies, Faculty of Engineering, Kyambogo University Uganda *Corresponding author: ainbinsafs@gmail.com
\end{abstract}

\begin{abstract}
Concrete has been the world's most consumed construction material, with over 10 billion tons of concrete annually. This is mainly due to its excellent mechanical and durability properties plus high mouldability. However, one of its major constituents; Ordinary Portland Cement is reported to be expensive and unaffordable by most low-income earners. Its production contributes about $5 \%-8 \%$ of global $\mathrm{CO}_{2}$ greenhouse emissions. This is most likely to increase exponentially with the demand of Ordinary Portland Cement estimated to rise by $200 \%$, reaching 6000 million tons/year by 2050 . Therefore, different countries are aiming at finding alternative sustainable construction materials that are more affordable and offer greener options reducing reliance on non-renewable sources. Therefore, this study aimed at assessing the possibility of utilizing sugarcane bagasse ash from co-generation in sugar factories as supplementary material in concrete. Physical and chemical properties of this sugarcane bagasse ash were obtained plus physical and mechanical properties of fresh and hardened concrete made with partial replacement of Ordinary Portland Cement. Cost benefit analysis of concrete was also assessed. The study was carried using 63 concrete cubes of size $150 \mathrm{~cm}^{3}$ with water absorption studied as per BS 1881-122; slump test to BS 1881102; and compressive strength and density of concrete according to BS 1881-116. The cement binder was replaced with sugarcane bagasse ash $0 \%, 5 \%, 10 \%, 15 \%, 20 \%, 25 \%$ and $30 \%$ by proportion of weight. Results showed the bulk density of sugarcane bagasse ash at $474.33 \mathrm{~kg} / \mathrm{m}^{3}$, the specific gravity of 1.81 , and $65 \%$ of bagasse ash has a particle size of less than $0.28 \mathrm{~mm}$. Chemically, sugarcane bagasse ash contained $\mathrm{SiO}_{2}$, $\mathrm{Fe}_{2} \mathrm{O}_{3}$, and $\mathrm{Al}_{2} \mathrm{O}_{3}$ at $63.59 \%, 3.39 \%$, and $5.66 \%$ respectively. A $10 \%$ replacement of cement gave optimum compressive strength of $26.17 \mathrm{MPa}$. This $10 \%$ replacement demonstrated a cost saving of $5.65 \%$ compared with conventional concrete. Meanwhile, water absorption increased with sugarcane bagasse ash proportions due to an increase in finer silica content. In conclusion, sugarcane bagasse ash produced in cogeneration boilers, when used in raw form without re-burning does not yield amorphous silica type to facilitate the pozzolanic reaction. However, a $10 \%$ replacement could be used and maintain $25 \mathrm{MPa}$ concrete, with some cost savings hence, more sustainable.

Keywords: Co-generation, Ordinary Portland Cement, Physical \& Mechanical properties, Sugarcane bagasse ash.
\end{abstract}

Cite as: Ainomugisha et al., (2021). Utilization of Sugarcane Bagasse Ash from Power Co-generation Boilers as a Supplementary Cementitious Material. East African Journal of Science, Technology and Innovation 2(2).
Received: $\quad 27 / 05 / 20$

Accepted: $\quad 19 / 01 / 21$

Published: 25/03/21

\section{Introduction}


The construction industry continues to play a pivotal role in any nation's development and grows rapidly than most sectors. In this industry, concrete is reported as the most commonly used (Bentur, 2002) and plays an inherent role. Its dominance in construction stems from its excellent mechanical properties such as compressive strength, high mouldability, durability, and fire resistance (Mishra and Deodhar, 2008). This makes it highly applicable in the construction of buildings and civil structures like dams, pavements, bridges and stadiums among others.

However, over the years, its use has been hampered by its expensive ingredient of cement, accounting for about $45 \%$ cost of concrete (Pacheco-Torgal and Jalali, 2010). The production of cement emits greenhouse gas of $\mathrm{CO}_{2}$, with 6$8 \%$ of environmental $\mathrm{CO}_{2}$ attributed to Ordinary Portland Cement (OPC) (Cordeiro et al., 2008). This is so because 1 ton of $\mathrm{CO}_{2}$ is generally emitted from 1 ton of OPC manufactured (Kamau and Ahmed, 2017). Cement manufacturing also consumes a great deal of the world's natural resources, with most of them being non-renewable. Studies have indicated that it requires about 1.6 tons of natural resources to output 1 ton of cement (Broomfield, 2007). This is likely to result in depletion of these worlds' natural resources if alternative sustainable options are not developed. Therefore, this study is a continuation of other previous studies that have been developed in a bid to avert the challenges associated with concrete. Many studies have tried to utilize agricultural, industrial, and agro-industrial by-products in the concrete making while trying to maintain the required quality parameters of concrete (Azhagarsamy and Jaiganesan, 2016).

Some studies have studied the utilization of rice husk ash (Zareei et al., 2017; Islam et al., 2019); maize cob ash (Shakouri et al., 2020); fly ash (Hemalatha and Ramaswamy, 2017 and Shaikuthali et al., 2019) and Sugarcane bagasse ash (Srinivasan and Sathiya, 2010; Kennedy et al., 2015; Venkatesh and Pradeepa, 2019; and Loganayagan et al., 2020).

SCBA, a by-product generally produced in sugar factories after burning bagasse, a fibrous residue obtained after crushing canes to produce sugar has been selected for further study in this research. It was selected mainly because many sugar factories have started utilizing this residue in the co-generation of power. It's approximately $135 \mathrm{kgs}$ (about $13.5 \%$ ) of bagasse by dry weight consisting of mainly cellulose and hemicellulose up to about $70 \%$ (Stanmore, 2010). It's also because Sugarcane growing is one of the most common economic activities taking place around the world where approximately $1,907 \mathrm{~m}$ tons are produced annually (Food and Agricultural Organization, 2018). In East Africa, about 36m tons are grown annually which produces approximately $4.86 \mathrm{~m}$ tons of bagasse. In Uganda, Kakira sugar works, Sail Kaliro, and Kinyara sugar works are ones mainly utilizing this fibrous residue to generate electricity in electric cogeneration boilers (Electricity Regulatory Authority, 2018). The co-generation of bagasse for fuel as seen in the sugar factories in East Africa has the potential of generating considerable high amounts of SCBA. This is so because each ton of fibrous bagasse has potential of producing between $25-40 \mathrm{~kg}$ of ash by dry weight (Sales and Lima, 2010). As cited in a number of literatures, SCBA has been covered extensively in many regions. However, given that the chemical contents do vary greatly due to difference in environmental conditions. For example, a combination of the three elements contributing to the pozzolanic reaction of $\mathrm{Fe}_{2} \mathrm{O}$; $\mathrm{Al}_{2} \mathrm{O}_{3}$, and $\mathrm{SiO}_{2}$ can vary so widely, Srinivasan and Sathiya (2010) 90.5\% for the three; $95.29 \%$ in Loganayagan et al., (2020); 73\% in Venkatesh and Pradeepa (2019); 70.48\% Anupam et al. (2013) and as low as $40.66 \%$ (James and Pandian (2018), and 71.22\% (Barasa et al., (2015) done in Kenya. Therefore, since there a paucity of literature in the East African region, more studies are still needed.

The SCBA, produced from electric power cogeneration, has been selected because according to some of the latest researches like Arif et al., (2017), subjecting sugarcane bagasse to uncontrolled temperatures can vary the quartz content. The quartz polymorph is altered from acristobalite for the silica produced to a-quartz, which makes it serve as a filler. This is because aquartz is non-pozzolanic (Arif et al., 2017). As a filler, this SCBA tends to act mostly as a fine aggregate, filling the voids within the concrete 
made. This consequently improves the density, strength, and durability of concrete (Topcu et al., 2009). Since some of the researchers report bagasse produced sometimes with mere open-air burning, there is need to investigate case study bagasse ash from power co-generation boilers.

According to Cordeiro et al. (2009), SCBA produces some pozzolanic characteristics since it may contain amorphous silica. Srinivasan and Sathiya (2010) whose pozzolanic component in SCBA were $90.5 \%$, obtained an increase in compressive and tensile strength up to $10 \%$ cement replacement (Bheel et al., 2019) assessed the tensile and compressive strengths of concrete made with cement replacement at $0 \%$ to $20 \%$ and established increase in those strengths by $15.40 \%$ and $8.5 \%$ respectively at $10 \%$ replacement. As for Rajasekar et al., (2018), he established an optimum $15 \%$ replacement to be possible while making ultra-high strength concrete. Praveenkumar and Sankarasubramanian, (2019) used SCBA as pozzolana in high strength concrete for cement replacements between $0 \%$ $20 \%$ and obtained optimum incorporation of this SCBA at $10 \%$. The ash was produced by burning at temperatures less than $700^{\circ} \mathrm{C}$.

The SCBA produced from co-generation normally results in samples of ash with a large specific surface area (Cordeiro et al., 2008; Ganesan et al., 2007) than one generated at uncontrolled temperatures. This study will enable deep internalization of the SCBA as a supplementary material in concrete making.

Therefore, this study presents findings of an assessment of the possibility of utilizing SCBA produced under co-generation in boilers as supplementary cementitious material, partially replacing cement in concrete making.

\section{Materials and Methods}

\section{Coarse, Fine Aggregates, and Sugarcane Bagasse Ash}

Fine aggregates in form of lake sand and crushed aggregates size $14-20 \mathrm{~mm}$ were obtained from a materials yard in Kalerwe town, Kyebando Parish, Kawempe Kampala city Uganda. The sand of the minimum void ratio was selected to give the necessary voids for water mixing. The physical properties of the sand are as presented in Table 1.

The sieve analysis (Figure 1) method for coarse and fine aggregates was used to primarily determine the grading of materials being used. The results were used to determine the compliance of the particle size distribution with applicable specification required. The tests were carried following the requirements of BS EN 1015-1 (1998).

Table 1: Physical properties of fine and coarse aggregates plus SCBA

\section{Sr. No. \\ Properties Fine Aggregates Coarse Aggregates Sugarcane bagasse ash}

\begin{tabular}{llccc}
\hline $\mathbf{1}$ & Bulk Density & $1661.3 \mathrm{~kg} / \mathrm{m}^{3}$ & $1580 \mathrm{~kg} / \mathrm{m}^{3}$ & $474.33 \mathrm{~kg} / \mathrm{m}^{3}$ \\
$\mathbf{2}$ & Specific gravity & 2.61 & 2.77 & 1.81 \\
$\mathbf{3}$ & Particle size & $0.15 \mathrm{~mm}-15 \mathrm{~mm}$ & $14 \mathrm{~mm}-20 \mathrm{~mm}$ & Less than $0.28 \mathrm{~mm}$ \\
$\mathbf{4}$ & Fineness Modulus & 2.91 & 3.8 & \\
$\mathbf{5}$ & Water Absorption & 8.43 & 0.66 & \\
$\mathbf{6}$ & AIV & - & 17.82 &
\end{tabular}




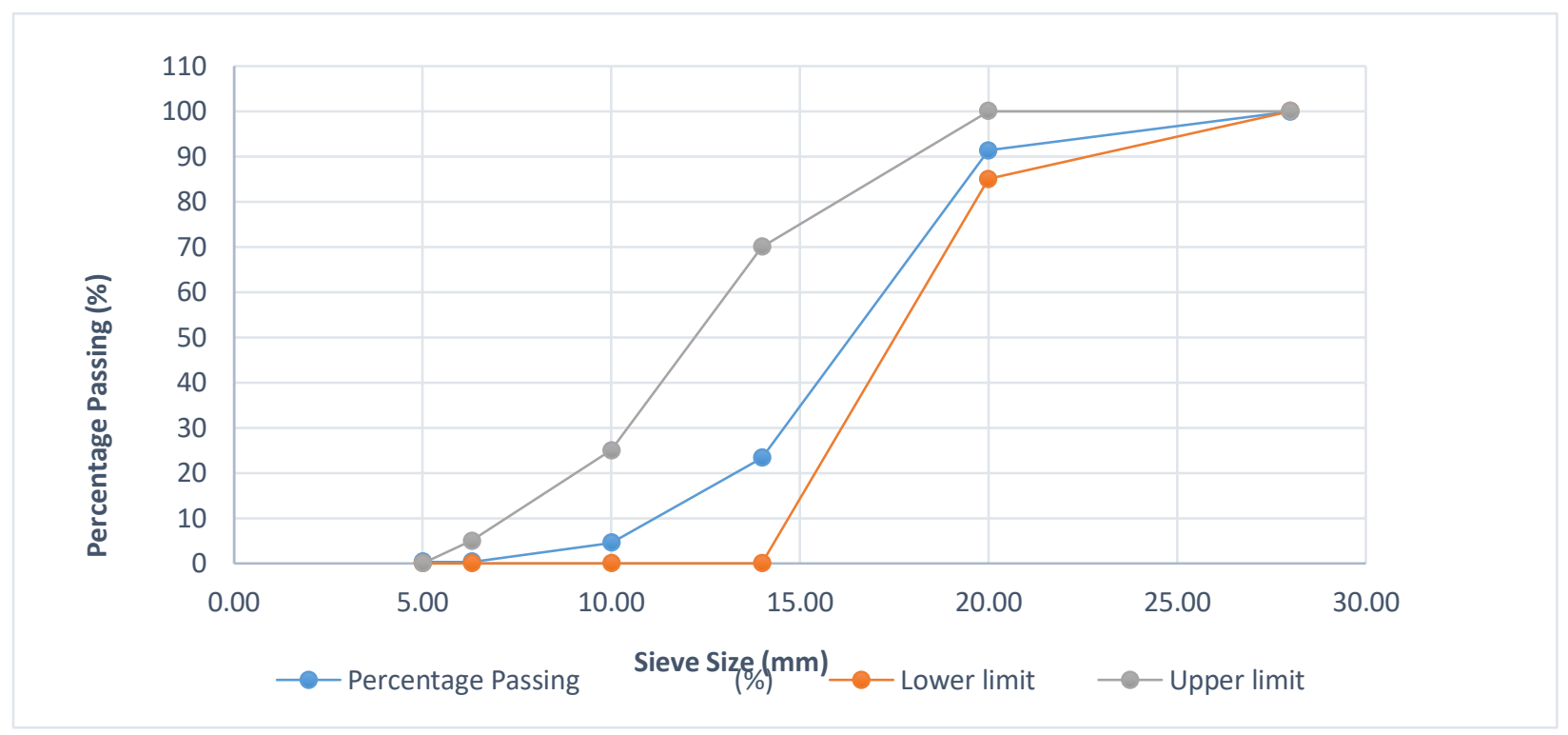

Figure 1: Particle size distribution curve of coarse aggregates

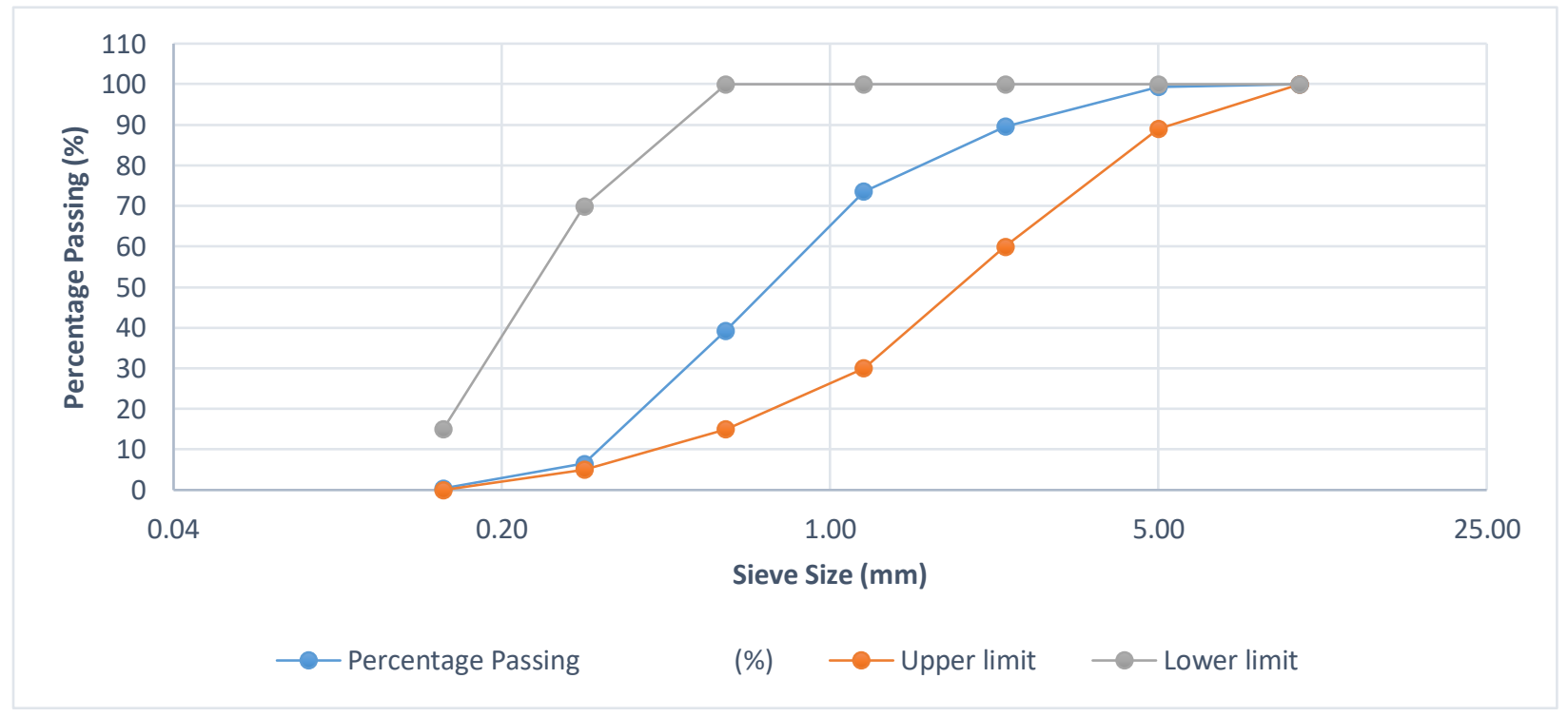

Figure 2: Particle distribution curve for fine aggregates 
The sugarcane bagasse ash used (figure 4) was obtained from Kakira Sugar Works located in Jinja-Eastern Uganda. This is the biggest sugar processing plant using bagasse for power generation and according to the Electricity Regulatory Authority (ERA) (2018). This factory crushes about 7000tons of cane per day and this generates about 340,200tons of bagasse annually. Hence, after using it for power co-generation, it leaves behind approximately 13,608 tons of SCBA annually. These power co-generation boilers operate at about $530^{\circ} \mathrm{C}$.

Table 2: Chemical composition of SCBA
Then SCBA was sundried (Figure 5a), standardized by performing sieving using a $300 \mu \mathrm{m}$ sieve, hence able to attain high silica content (Bahurudeen and Santhanam, 2015). To establish the potential of pozzolanicity material within this SCBA, chemical analysis was done with an X-ray Fluorescence Spectrometer Machine (XRF) of X-5000 series (Table 2). This was in line with the characterization of Madurwar et al., (2014). Physical properties were also established for this SCBA as summarized in Table 1.

\section{Pozzolan}

SCBA \%

Parameter

Class F, ASTM C618

\begin{tabular}{|c|c|c|}
\hline $\mathrm{Al}_{2} \mathrm{O}_{3}$ & & 5.66 \\
\hline $\mathrm{Fe}_{2} \mathrm{O}_{3}$ & & 3.39 \\
\hline $\mathrm{SiO}_{2}$ & & 63.59 \\
\hline & Min $70 \%$ & $72.64 \%$ \\
\hline $\mathrm{SiO}_{3}$ & & 1.3 \\
\hline $\mathrm{CaO}$ & & 3.19 \\
\hline $\mathrm{MgO}$ & & 0.75 \\
\hline $\mathrm{Na}_{2} \mathrm{O}$ & & 0.62 \\
\hline
\end{tabular}

The chemical constituents of SCBA sampled satisfies class $\mathrm{F}$ requirements of ASTM C618-05 (2005) of at least $70 \%$ in total of $\mathrm{SiO}_{2}+\mathrm{Al}_{2} \mathrm{O}_{3}+$ $\mathrm{Fe}_{2} \mathrm{O}_{3}$. Therefore, it has a capacity of being used in concrete and behaves like Class F Fly Ash, in its engineering properties. Particle size distribution (Figure 3) for SCBA was determined by hydrometer analysis test conforming to BS1377: Part 2:1990.

\section{Technology Description}

\section{Batching and Mixing}

The batching followed the design mix ratio that was obtained using the American Concrete
Institute (ACI) method, with a target concrete compressive strength of $25 \mathrm{MPa}$. The replacement of cement was done by weight in percentages of $5 \%, 10 \%, 15 \%, 20 \%, 25 \%$, and $30 \%$ of the cement weight. The weighed coarse aggregates were placed on a moist metallic tray used as a mixing pan, then followed by fine aggregates, then OPC and SCBA in that respective order. The cubic moulds were cleaned and oiled properly (Figure 4a). The concrete cubes were cast in these steel moulds of dimensions $150 \mathrm{~mm} \times 150 \mathrm{~mm} \times 150 \mathrm{~mm}$ conforming to BS EN 12390-1, (2000). 


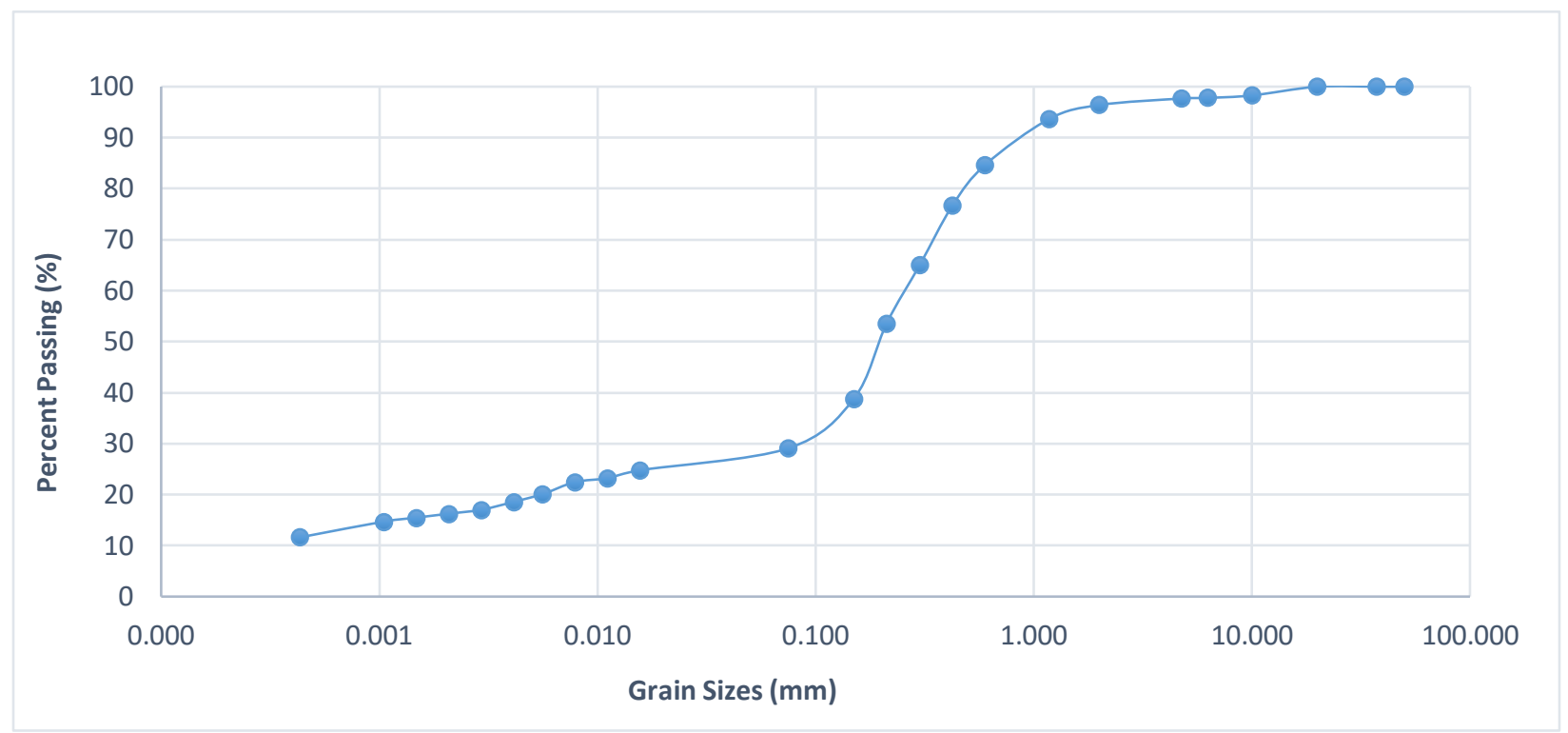

Figure 3: Particle size distribution of SCBA

After casting, the concrete cubes were removed from the moulds (Figure $4 \mathrm{~b}$ ), weighed and placed
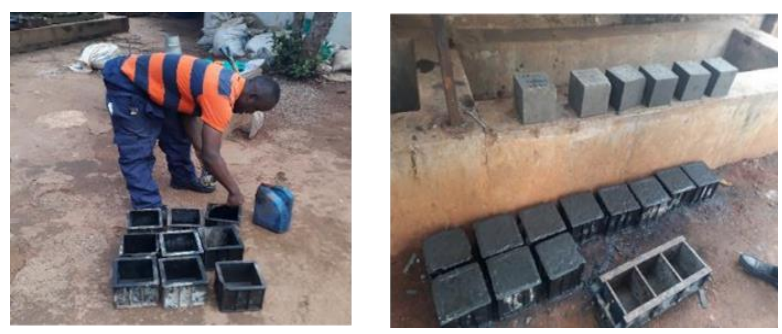

Figure 4: (a) Preparing of molds for casting; (b) cast concrete cubes

\section{Test Methods}

Physical Properties of Fresh Concrete

To establish the workability of fresh concrete made with partial replacement of cement by SCBA, a slump test was done. It was carried out by filling a corn mould with freshly mixed concrete and measuring the slump after removal of the mould (Figure 5). In this study, a slump test was carried out on every batch of freshly mixed concrete conforming to (BS 1881-102, 1983). in the curing tank, until the time of testing them after 7,14 , and 28 days respectively.

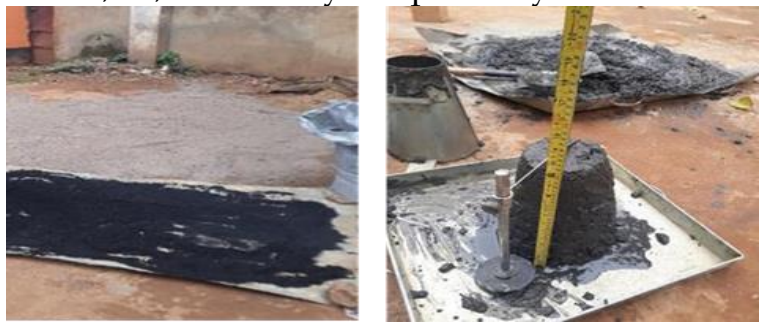

Figure 5: (a) Sun drying of sugarcane bagasse ash; (b) measuring slump

On the other hand, water absorption resulting from the permeability of concrete made with SCBA replacement to cement at percentages of $5 \%, 10 \%, 15 \%, 20 \%, 25 \%$, and $30 \%$ SCBA. This was performed in relation to the control mix for cubes made after 7 days, 14 days and 28 days of curing times as displayed in figure 5 .

Density of concrete

The density of concrete was determined following BS 1881-114 (1983). It was established at 7, 14, and 28 days of curing, nine (9) times for each mix that was made and an average obtained. Compressive strength 
This test was carried out in accordance with BS 1881-116 (1983) using an Electro-Hydraulic Compression Testing Machine (figure 6). To perform this test, concrete cubes obtained from the curing tank at test times of 7,14, and 28days were placed and centered in between the plates. Three sets of specimens were crushed for each percentage replacement and the average obtained and recorded in $\mathrm{MPa}$.

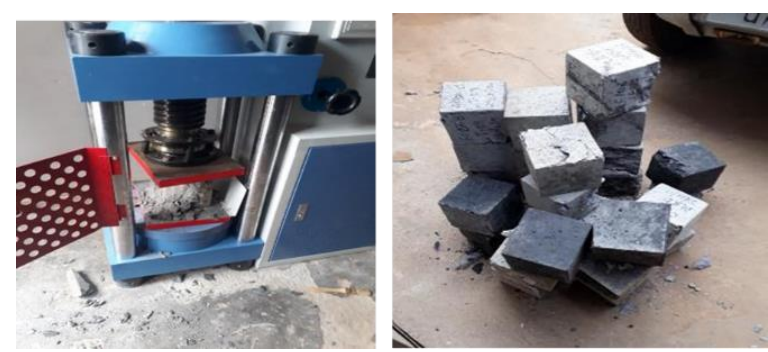

Figure 6: Electro Hydraulic Compression Testing Machine DKW-300 with crushed specimens

\subsection{Cost Analysis of Concrete}

Cost analysis of concrete without SCBA was carried out to come up with a cost per cubic meter and then compared with the cost of concrete with an optimum amount of sugarcane bagasse ash. The deviation in the costs of concrete gave an analysis of the cost impact of sugarcane bagasse ash replacement as an admixture. Analysis of rates for cement concrete (C25) mix ratio 1:2:3 with cement partially replaced at different percentages from $5 \%-30 \%$ of SCBA, was done basing on prevailing market rates.

Some of the cost constants used were: wastage $5 \%$; Labour constant for skilled labour at $0.6 \mathrm{hrs}$ and unskilled labour at $1.2 \mathrm{hrs}$; the cost of skilled per hour $=$ US $\$ 0.844$ and unskilled labour per hour $=$ US $\$ 0.507$. In general, the costs were built based on methods used by estimators in building up rates of items described in Standard Method of Measurement, $7^{\text {th }}$ Edition (SMM7) (Buchan et al., 2012). The unit cost per cubic metre built was an all-in rate which covers labour, materials, plant plus necessary profits and overheads.

\section{Results}

The SCBA sample picked from the power cogeneration boilers had a very high content of silica up to $63.59 \%$. The three components that characterize pozzolanic reaction in calcinated natural materials of silica, alumina, and ferric oxide gave $72.64 \%$ which was above $70 \%$ specified for class F pozzolan (ASTM C618-05, 2012). The high content of $\mathrm{SiO}_{2}$ is attributed to some coarser quartz particles adhering to the sugarcane bagasse surface which are harvested alongside the sugarcane bagasse (Cordeiro et al., 2011).

\section{Workability}

Considering a fixed water-cement ratio of 0.61 , when the SCBA content was increased in the concrete mix, there was a reduction in workability levels. This indicates there was reduction of quality of concrete with respect to consistency. This was indicated by a reduction in slump values. The slump reduced from $190 \mathrm{~mm}$ of normal concrete to $30 \mathrm{~mm}$ from $0 \%$ to $30 \%$ replacement of cement with SCBA (Figure 7). This means there was rapid reduction in slump with continuous addition of SCBA by about $533.3 \%$ reduction. The initial replacement of 5\% gave a slump reduction of $18.8 \%$ while the $10 \%$ replacement gave slump reduction of $35.7 \%$ from normal concrete without SCBA. This implied SCBA impacts negatively on the workability of concrete.

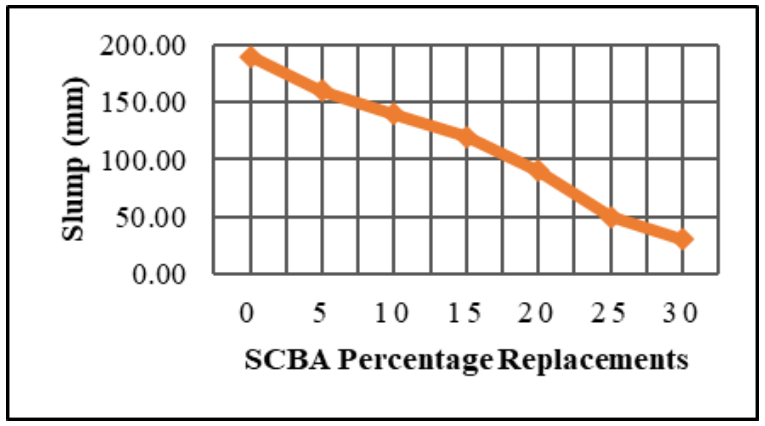

Figure 7: Variation of slump with cement replacement by SCBA

\section{Water absorption}

The percentage of water absorption increases with increase in the SCBA content substitution for cement in the mix (Figure 8). The measure of water permeability indicates the number of pores within the concrete after hardening or the porousness of concrete as seen in Figure 8. It increased with the addition of SCBA. 


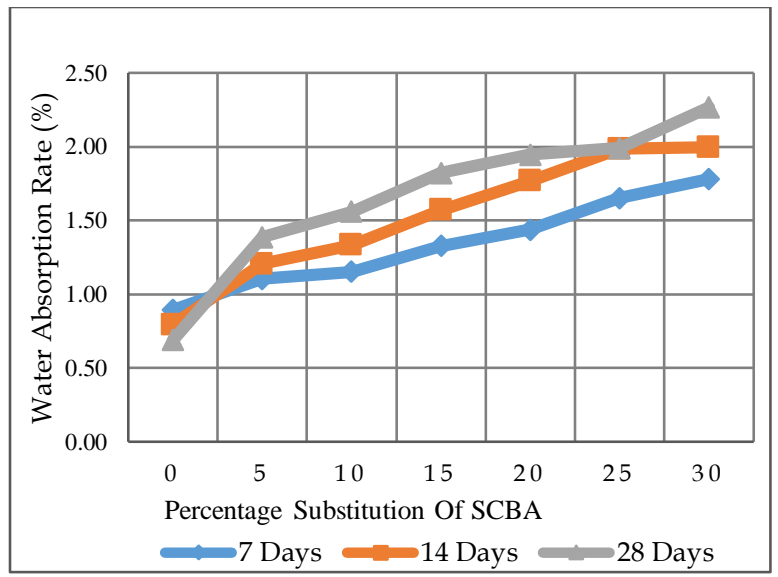

Figure 8: Water absorption rate of hardened concrete

Overall, the water permeability increased by $229 \%$ as SCBA replacement of cement increased from $0 \%$ to $30 \%$ i.e. water absorption rate increased from $0.69 \%$ to $2.27 \%$. The highest water absorption rate increase at 28 days of $101 \%$ was obtained when SCBA was first introduced i.e. at $5 \%$ replacement. Later, this water absorption rate increased gradually at a mean of $10.32 \%$ when SCBA composition was incremented at $5 \%$ for 28 days of curing. At all curing ages, the water absorption rate increased with percentage replacement of cement with SCBA i.e. by $100 \%$ and $153 \%$ for 7 and 14 days respectively.

\section{Density of Concrete}

Low weight concrete is generally produced when cement is partially replaced with wastes of SCBA from co-generation boilers. The density of concrete at 7 days was generally slightly greater than that at 28 days for all the substitutions. There was a reduction in the density of concrete with an increase in the percentage of OPC substitution with SCBA. At 28 days of curing, percentage decrease of $11.2 \%$ was recorded for replacement from $0 \%$ to $30 \%$ SCBA (Table 3). The cumulative percentage decrease in density at 28 days of curing was high than that at 7 and 14 days of curing.

Table 3: Density of concrete and percentage decrease with Increase in \% of SCBA

\begin{tabular}{|c|c|c|c|c|c|c|}
\hline \multirow{3}{*}{$\%$ of SCBA } & \multicolumn{3}{|c|}{ Density of Concrete $\left(\mathrm{Kg} / \mathrm{m}^{3}\right)$} & \multicolumn{3}{|c|}{ Cumulative Percentage Increase } \\
\hline & \multirow{2}{*}{7 Days } & \multirow{2}{*}{14 Days } & \multirow{2}{*}{28 Days } & & & \\
\hline & & & & 7 Days & 14 Days & 28 Days \\
\hline 0 & $2,333.83$ & $2,326.62$ & $2,340.94$ & & & \\
\hline 5 & $2,328.40$ & $2,329.48$ & $2,302.62$ & 0.23 & 0.43 & 1.64 \\
\hline 10 & $2,314.27$ & $2,316.54$ & $2,309.33$ & 0.83 & 0.12 & 1.35 \\
\hline 15 & $2,276.05$ & $2,322.96$ & $2,262.22$ & 2.48 & 0.15 & 3.36 \\
\hline 20 & $2,267.65$ & $2,178.86$ & $2,204.44$ & 2.84 & 6.35 & 5.83 \\
\hline 25 & $2,219.56$ & $2,176.30$ & $2,187.95$ & 4.9 & 6.46 & 6.54 \\
\hline 30 & $2,103.21$ & $2,103.41$ & $2,079.51$ & 9.88 & 9.59 & 11.17 \\
\hline
\end{tabular}

It was found that between $5 \%-10 \%$ replacement is where the slightest decrease in the density of concrete was obtained of $1.35 \%$. 


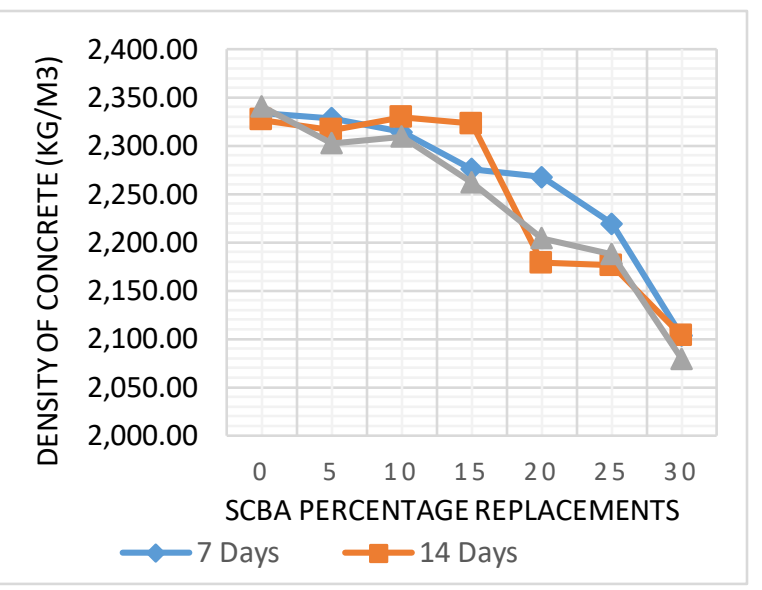

Figure 9: Density of concrete at different curing times

\section{Compressive Strength}

The compressive strength of concrete increased with curing time as all the 28 days compressive strength values were greater than those at 7 days and 14 days for all replacements of cement with SCBA (Figure 10). However, the increase in the SCBA content reduced the compressive strength from $31.61 \mathrm{MPa}$ to $10.74 \mathrm{MPa}$; a value much less than that of the control mix. The replacement of $5 \%, 10 \%, 15 \%, 20 \%, 25 \%$ and $30 \%$ SCBA reduced the compressive strength of normal concrete by $8.5 \%, 17.2 \%, 28.2 \%, 40 \%, 48.7 \%$ and $66 \%$ respectively at 28 days curing.

In relation to BS 5328 part 1 (1997), specification grade 25 concrete made with pure cement binder

Table 4: Cost analysis for different replacement levels

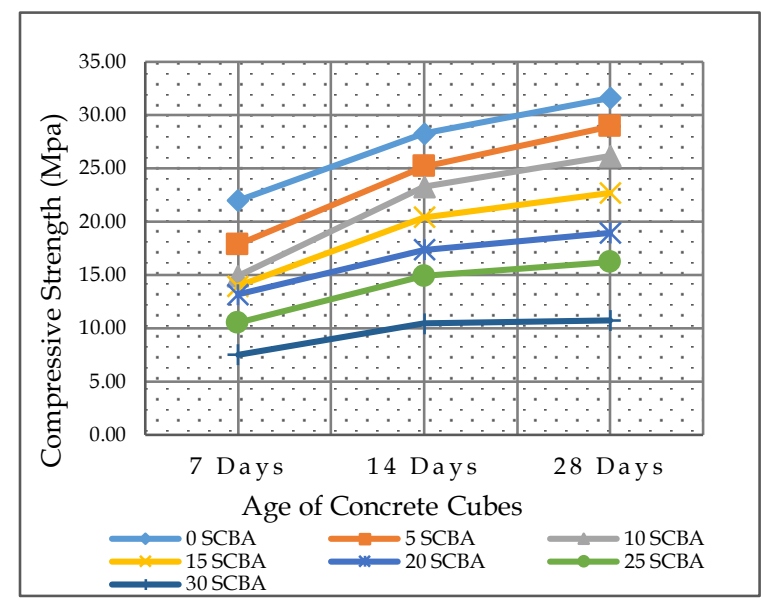

Figure 10: Compressive strength

should reach a compressive strength of $14 \mathrm{MPa}$, at 7 days of wet curing and $25 \mathrm{MPa}$ after 28 days, which was possible with $10 \%$ replacement. Hence optimum SCBA content that could be used while maintaining the required strength properties is at $10 \% \mathrm{SCBA}$, with $26.17 \mathrm{MPa}$ after 28 days.

\section{Cost Analysis}

The rate per cubic meter was found to reduce with the increase in the amount of SCBA with the percentage saving increasing from $2.82 \%, 5.65 \%$, $8.47 \%, 11.30 \%, 14.12 \%$, and $16.95 \%$ for $5 \%, 10 \%$, $15 \%, 20 \%, 25 \%$ and $30 \%$ respectively (Table 4 ).

\begin{tabular}{lccc}
\hline Amount of SCBA & ${\text { Cost } / \mathbf{m}^{\mathbf{3}} \mathbf{( \$ )}}$ & Saving $_{\mathbf{m}} \mathbf{m}^{\mathbf{3}} \mathbf{( \$ )}$ & Percentage saving \\
\hline $\mathbf{0 \%}$ & 142.45 & 0.00 & \\
$\mathbf{5 \%}$ & 138.42 & 4.02 & $2.82 \%$ \\
$\mathbf{1 0 \%}$ & 134.40 & 8.05 & $5.65 \%$ \\
$\mathbf{1 5 \%}$ & 130.38 & 12.07 & $8.47 \%$ \\
$\mathbf{2 0} \%$ & 126.36 & 16.09 & $11.30 \%$ \\
$\mathbf{2 5 \%}$ & 122.33 & 20.11 & $14.12 \%$ \\
$\mathbf{3 0} \%$ & 118.31 & 24.14 & $16.95 \%$ \\
\hline
\end{tabular}


Therefore, using SCBA for partial replacement of cement in making grade 25 concrete having attained optimum replacement at $10 \%$ could bring a saving of US\$8.05 about $5.65 \%$ cost saving.

\section{Discussion}

\section{Properties of Materials}

The water absorption for coarse aggregates was established as 0.66 which conforms within the requirement of less than 3.00 as per BS 5337:1998. The fineness modulus of the sand was between the range of $2.6-3.0$ showing that the sand used was of medium type i.e. falling between fine and coarse. The bulk density and loose density are in agreement with Lakshmi (2016). Meanwhile, AIV and ACV satisfied the maximum limits given in BS 882: 1992 of $45 \%$ and 30\% respectively. As obtained in Figure 2 the sand was within the envelope hence suitable for use in concrete. The grading was categorized as well-graded and this was in agreement with Kennedy et al., (2015) which was stated as good for pozzolanic activity with the use of SCBA in concrete.

Sugarcane bagasse ash had a bulk density of $474.33 \mathrm{~kg} / \mathrm{m}^{3}$ which is higher than that of Safayat et al., (2018), reported at $250 \mathrm{~kg} / \mathrm{m}^{3}$ but lower than one obtained by Ajay (2007) at $514 \mathrm{~kg} / \mathrm{m}^{3}$. This could be attributed to difference in temperatures at which SCBA is produced, whereby very high temperatures subjected to bagasse contribute to the number of open pores in the ash resulting in denser bagasse ash. This bulk density however was too low compared with that of cement which is $1440 \mathrm{~kg} / \mathrm{m}^{3}$.

Figure 1 shows the envelope (lower and upper limit curves) of coarse aggregates of the single sized aggregate of $14 \mathrm{~mm}$ referenced in BS 882: 1992 and since the curve for the coarse aggregates was within the envelope, therefore they were suitable for use in concrete.

The dark colour of the resultant SCBA is an indicator of high carbon content within the bagasse ash due to incomplete combustion (Cordeiro et al., 2008). This is synonymous with what was categorized as raw bagasse ash i.e. one produced in co-generation at around $500-550^{\circ} \mathrm{C}$
(Bahurudeen and Santhanam, 2015). This has an impact on pozzolanic activity with a high value of loss of ignition. The specific gravity was 1.81 and this was lower than some other studies like Praveenkumar and Sankarasubramanian, (2019); and Loganayagan et al., 2020), which was above 2.0. This was attributed to the existence of lightweight coarse fibrous particles within bagasse ash produced under co-generation (Bahurudeen and Santhanam, 2015). This difference would necessitate very high-water demand and would require the use of a high volume of SCBA used in same weight of replacement compared to others (Arif et al., 2017).

\section{Workability}

The $533 \%$ decline in the slump which results in stiff- lesser workable mix obtained when SCBA was used for OPC substitution is in disagreement with (Bheel et al., 2019). This reduction in slump indicates that the mixture of OPC: SCBA had a high-water demand to produce a workable concrete. This is generally attributed to the very low specific gravity of SCBA which was 1.81 compared to that of OPC. This increases the requirement for lubrication because in any given weight of replacement there is a considerable high volume of ash (Sales and Lima, 2010). An increase in water demand indicated by a decrease in slump could also be associated with high surface area and the porousness of the fine SCBA particles from the un-burnt component of carbon (Chusilp et al., 2009; Sales and Lima, 2010). More to that is the angularity within SCBA causing an increase in water demand as they increase catchment points (Arif et al., 2017).

\section{Water Absorption}

SCBA substitution of cement partially leads to the subsequent increase in water absorption. This finding agrees with Ganesan et al., (2007). The increase as seen in Figure 8 could be attributed to the introduction of the finer SCBA as compared with OPC plus its hygroscopic nature as stated by Ganasen et al., (2007). The higher water absorption is also attributed to high sorptivity which is due to use of raw SCBA with coarser, unburnt and half burnt particles which, due their porous nature absorbs more water (Prashant and Vyawahare, 2012). 


\section{Density of Concrete}

The bulk density decreased with the age of curing (Figure 9). This is because as the concrete hardens it uses up water in hydration. The products of hydration occupy less space than the original water and cement (Neville, 1995). The reduction in density could be as a result that SCBA had a less bulk density of $474.33 \mathrm{~kg} / \mathrm{m}^{3}$ as compared to that of OPC which was $1396.1 \mathrm{~kg} / \mathrm{m}^{3}$ and OPC having a higher specific gravity (3.15) than SCBA (1.81). It can be seen also that at low percentage replacement of cement with SCBA there is slight increase in density of concrete from 2,302.62 $\mathrm{Kg} / \mathrm{m}^{3}$ to $2,309.33 \mathrm{Kg} / \mathrm{m}^{3}$. This could be because at $10 \%$ replacement, SCBA serves as a micro-filler and triggers improvement in the density of cement paste (Rajasekar et al., 2018; Praveenkumar and Sankarasubramanian, 2019). This decrease in density of concrete with an increase in SCBA content is in agreement with (Srinivasan and Sathiya, 2010; and Abdulkadir et al., 2014).

\section{Compressive Strength}

This strength reduction could be an indicator that this SCBA did not contribute to strength gain. The significant reduction in compressive strength can be partly attributed to early age testing since pozzolanic reactions in pozzolans of silica and free Calcium oxide is reported absent at early curing and occur at long periods of curing (Heidari et al., 2019). Therefore, no significant reaction took place between silica from SCBA and calcium hydroxide from cement hence strength reduction (Praveenkumar and Sankarasubramanian, 2019). This is due to high carbon content which is evidenced in its black colour, hampering the production of amorphous silica. However, this could be improved by reburning the collected bagasse ash to temperatures about $600^{\circ} \mathrm{C}-700^{\circ} \mathrm{C}$ (Cordeiro et al., 2009). This is also seen in (Bahurudeen and Santhanam, 2015) who re-burnt raw bagasse ash to up to temperatures of $900^{\circ} \mathrm{C}$. Raw sugarcane bagasse ash from co-generation boilers had a pozzolanic activity value $(71 \%)$ lower than the required index of $75 \%$. Hence, the reason for the decrease in strength in this study was attributed to a raw sample being used.

\section{Conclusions}

The SCBA produced from power co-generation boilers is found to contain a suitable chemical composition of silica, alumina, and iron oxide corresponding to Class F of fly ash. Hence, chemical wise this SCBA could be used as a pozzolan. Sugar cane bagasse ash (SCBA) reduced the workability of fresh concrete with increasing percentages of SCBA. Therefore, its usage would require more water to improve its flowability. This is mainly due to low specific gravity and a high volume of ash per replacement. SCBA increased water absorption of concrete with increasing percentages of SCBA in the concrete mix which indicates more permeable concrete. Hence, only suitable for use in areas with limited exposure to water. The SCBA produced in co-generation boilers once used in raw form without re-burning does not yield amorphous silica type to facilitate the pozzolanic reaction. However, a small percentage replacement of SCBA up to $10 \%$ could be used and still maintain $25 \mathrm{MPa}$ concrete strength. The cost of the SCBA Concrete minimizes the costs of the ordinary concrete. Utilizing $10 \%$ SCBA as partial replacement of cement costs less than conventional concrete by $5.65 \%$, usable for normal structural works.

There is a need therefor to develop codes or guiding standards on the use of various wastes like sugar cane bagasse ash in concrete. This is likely to properly guide their application in the construction industry. Further research should be done on the effect of sugarcane bagasse ash on the physical and mechanical properties of concrete for longer days of curing say 56,90 , and 120 days. It is also recommended that continuous studies on the durability aspect of SCBA Concrete matrix in chloride and sulphate environments. This will help to establish whether usage of SCBA has appreciable resistance to chloride permeation and diffusion.

\section{References}

Abdulkadir, T. S., Oyejobi, D. O., \& Lawal, A. A. (2014). Evaluation of sugarcane bagasse ash as a replacement for cement in 
concrete works. Acta Technica Corviniensis-Bulletin of Engineering, 7(3), 71.

Ajay, G. H. (2007). Properties and Reactivity of Sugarcane Bagasse Ash. Retrieved from Http://soil.en.a.utokyo.ac.jp/jsidre/search/PDFs/07/070 06-35.pdf.

Anupam, A. K., Kumar, P., \& Ransinchung, G. D. Use of various agricultural and industrial waste materials in road construction. Procedia-Social and Behavioral Sciences, 104, 264-273, 2013. https://doi.org/10.1016/j.sbspro.2013.1 1.119 .

Arif, E., Clark, M. W., \& Lake, N. (2017). Sugar cane bagasse ash from a high-efficiency co-generation boiler as filler in concrete. Construction and Building Materials, 151, 692-703. https://doi.org/10.1016/j.conbuildmat. 2017.06.136.

ASTM, American Standards for Testing and Materials, 2005. Standard C618-05 "Standard specification for coal fly ash and raw or calcined natural pozzolan for use in concrete"

Azhagarsamy, S., \& Jaiganesan, K. (2016). A study on strength properties of concrete with rice husk ash and silica fume with addition of glass fiber. International Research Journal of Engineering and Technology, 3(8), 1681-1684.

Bahurudeen, A., \& Santhanam, M. (2015). Influence of different processing methods on the pozzolanic performance of sugarcane bagasse ash. Cement and Concrete Composites, 56, 32-45. https://doi.org/10.1016/i.cemconcomp. 2014.11.002

Barasa, P. K., Too, D., Jonah, K., \& Mulei, S. M (2015). Stabilization of expansive clay using lime and sugarcane bagasse ash. Int. J. Sci. Res. (IJSR), 4(4), 2112-2117.

Bentur, A. (2002). Cementitious materials - nine millennia and a new century: past, present, and future. Journal of materials in civil engineering, 14(1), 2-22. https://doi.org/10.1061/(ASCE)08991561(2002)14:1(2)

Modani, P. O., \& Vyawahare, M. R. (2013). Utilization of bagasse ash as a partial replacement of fine aggregate in concrete. Procedia Engineering, 51(0), 2529.

Cordeiro, G.C.; Filho, R.D.; de Almeida, R.S. Influence of ultrafine wet grinding on pozzolanic activity of submicrometre sugar cane bagasse ash. Adv. Appli.Ceram. 2011, 110, 453-456.

Bheel, N., Abbasi, R. A., Sohu, S., Abbasi, S. A., Abro, A. W., \& Shaikh, Z. H. (2019). Effect of Tile Powder Used as a Cementitious Material on the Mechanical Properties of Concrete. Engineering, Technology \& Applied Science Research, 9(5), 4596-4599.

British Standard Institution (1993). Method for determination of slump BS 1881-102. British Standard Institution, London.

Broomfield J. P. (2007), "Corrosion of Steel in Concrete, Understanding, Investigation, and Repair", Second ed., E \& FN SPON, an imprint of Chapman \& Hall.

BS 1348-2, (1980), Test of Water for making Concrete, British Standards Institution, London, UK.

BS 1881-114. Test concrete-Part 114: methods for determination of density of hardened concrete. British Standards Institution; 1983.

BS 812: Part 112, Methods for Determination of Aggregate Impact Value (AIV), British Standards Institution, London, United Kingdom, 1990.

British Standard 1377-2:1990, Methods of Test for Soils for Civil Engineering Purposes Part 2: Classification Tests. British Standard Institution, London: UK.BSEN. (1998). 1015-1. Methods of Test for Mortar for Masonry-Part 1: Determination of Particle Size Distribution (By Sieve Analysis).

Buchan, R. D., Fleming, E., \& Grant, F. (2012). Estimating for builders and surveyors. Routledge.

Chusilp, N., Jaturapitakkul, C., \& Kiattikomol, K. (2009). Effects of LOI of ground bagasse ash on the compressive strength and sulfate resistance of mortars. Construction and Building Materials, 23(12), 35233531.https://doi.org/10.1016/j.conbuil dmat.2009.06.046 
Clark, M. W., Despland, L. M., Lake, N. J., Yee, L. H., Anstoetz, M., Arif, E., ... \& Doumit, P. (2017). High-efficiency cogeneration boiler bagasse-ash geochemistry and mineralogical change effects on the potential reuse in synthetic zeolites, geopolymers, cements, mortars, and concretes. Heliyon, 3(4), e00294. https://doi.org/10.1016/j.heliyon.2017. e00294.

Cordeiro, G. C., Toledo Filho, R. D., \& Fairbairn, E. D. M. R. (2008). Use of ultra-fine sugar cane bagasse ash as mineral admixture for concrete. ACI Materials Journal, 105(5), 487.

Cordeiro, G. C., Toledo Filho, R. D., \& Fairbairn, E. M. R. (2009). Effect of calcination temperature on the pozzolanic activity of sugar cane bagasse ash. Construction and building materials, 23(10), 3301-3303. https://doi.org/10.1016/i.conbuildmat. 2009.02.013.

Electricity Regulatory Authority (ERA) (2018). Energy Generated by Bagasse Power Plants. Retrieved from https://www.era.or.ug/index.php/stat s/generation-statistics/energygenerated-bagasse-power-plants. Accessed on $5^{\text {th }}$ January 2020.

EN, B. (2000). 12390-1," Shape, Dimensions and other Requirements for Specimens and Moulds. British Standard Institution.

Food and Agricultural Organization of the United States (FAOSTAT), (2018). Production quantities of sugarcane. https://www.fao.org/faostat/en/\#data $\angle \mathrm{QC} /$ visualize. Accessed on $10^{\text {th }}$ January 2020

Ganesan, K., Rajagopal, K., \& Thangavel, K. (2007). Evaluation of bagasse ash as supplementary material. Cement and concrete composites, 29(6), 515-524. https://doi.org/10.1016/j.cemconcomp. 2007.03.001.

Goyal, A., Kunio, H., \& Hidehiko, O. (2007). Properties and Reactivity of Sugarcane Bagasse Ash.

Hemalatha, T., \& Ramaswamy, A. (2017). A review on fly ash characteristicsTowards promoting high volume utilization in developing sustainable concrete. Journal of cleaner production, 147, 546-559.

https://doi.org/10.1016/j.jclepro.2017.0 1.114.

Heidari, A., Tavakoli, S., \& Tavakoli, D. (2019). Reusing Waste Ceramic and Waste Sanitary Ware in Concrete as Pozzolans with Nano-Silica and Metakaolin. International Journal of Sustainable Construction Engineering and Technology, 10(1). Retrieved from https://publisher.uthm.edu.my/ojs/in dex.php/IJSCET/article/view/4863.

Islam, R., Panchal, A., \& Kaushal, N. (2019). Review paper on replacement of cement with Rice husk Ash in Concrete. Our Heritage, 67(7), 278-285.

James, J., \& Pandian, P. K. Select geotechnical properties of a lime stabilized expansive soil amended with bagasse ash and coconut shell powder. Selected Scientific PapersJournal of Civil Engineering, 13(s1), 4560 , 2018. https://doi.org/10.1515/sspjce-20180005.

Kamau, J. \& Ahmed, A. (2017) "Suitability of Maize Cob Ash as a Partial Cement Replacement", Juniper online journal Material Science, vol. 2 no. 5, pp: 01-03.

Kennedy, A. Onchiri, R. Dr. \& Waswa, G. Dr. "Pozzolanic Activity of Sugarcane Bagasse Ash Concrete," international Journal of Recent Research in Physics and Chemical Sciences (IJRRPCS), vol. 1, no. 2, pp. 29-35, 2015.

Lakshmi, Priya, R. k and R, "EFFECT OF SUGARCANE BAGASSE ASH ON STRENGTH PROPERTIES OF CONCRETE," International Journal of Research in Engineering and Technology (IJRET), vol. 5, no. 4, pp. 159-164, 2016.

Loganayagan, S., Mohan, N. C., \& Dhivyabharathi, S. (2020). Sugarcane bagasse ash as alternate supplementary cementitious material in concrete. Materials Today: Proceedings. https://doi.org/10.1016/j.matpr.2020.0 3.060.

Madurwar, M. V., Mandavgane, S. A., \& Ralegaonkar, R. V. (2014). Use of sugarcane bagasse ash as brick material. Current Science, 1044-1051. 
https://www.jstor.org/stable/24110885

Mishra, S. and Deodhar, S. (2008). "Effect of Rice Husk Ash on Concrete," Nbmcw, no. 87, p. 33-39.

Neville, A.M. (1995) Properties-of-Concrete-AM 149. 4th Edition, Addison Wesley Longman Ltd., Essex.

Praveenkumar, S., \& Sankarasubramanian, G. (2019). Mechanical and durability properties of bagasse ash-blended highperformance concrete. SN Applied Sciences, 1(12), 1664. https://doi.org/10.1007/s42452-019$\underline{1711-x}$

Rajasekar, A., Arunachalam, K., Kottaisamy, M., \& Saraswathy, V. (2018). Durability characteristics of Ultra High Strength Concrete with treated sugarcane bagasse ash.Construction and Building Materials, 171, 350-356. https://doi.org/10.1016/j.conbuildmat. 2018.03.140.

Safayat, M., Islam, M., Rubieyat, B. A., \& Hasan, M. (2018). Investigation on the workability and compressive strength of concrete by using bagasse ash from sugar mill. World Scientific News, 96, 191-201.

Sales, A., \& Lima, S. A. (2010). Use of Brazilian sugarcane bagasse ash in concrete as sand replacement. Waste Management, 30(6), 1114-1122. https://doi.org/10.1016/j.wasman.2010 .01 .026 .

Shaikuthali, S. A., Mannan, M. A., Dawood, E. T., Teo, D. C. L., Ahmadi, R., \& Ismail, I. (2019). Workability and compressive strength properties of normal weight concrete using high dosage of fly ash as cement replacement. Journal of Building Pathology and Rehabilitation, 4(1), 26. https://doi.org/10.1007/s41024-0190065-5.

Shakouri, M., Exstrom, C. L., Ramanathan, S., \& Suraneni, P. (2020). Hydration, strength, and durability of cementitious materials incorporating untreated corn cob ash. Construction and Building Materials, 243, 118171. https://doi.org/10.1016/j.conbuildmat. 2020.118171.

Srinivasan, R., \& Sathiya, K. (2010). Experimental study on bagasse ash in concrete. International Journal for Service Learning in Engineering, Humanitarian Engineering and Social Entrepreneurship, 5(2), 60-66.

Standard, B. (1881). Testing concrete-Part 116: method for determination of compressive strength of concrete cubes. BS, 116, 1983.

BS 5328: Part 1: 1997. Concrete: Guide to specify concrete. BSI, London, UK.

Stanmore, B. R. (2010). Generation of energy from sugarcane bagasse by thermal treatment. Waste and Biomass Valorization, 1(1), 77-89. https://doi.org/10.1007/s12649-0099000-3.

Topcu, I. B., Bilir, T., \& Uygunoğlu, T. (2009). Effect of waste marble dust content as filler on properties of self-compacting concrete. Construction and building Materials, 23(5), 1947-1953. https://doi.org/10.1016/j.conbuildmat. 2008.09.007.

Venkatesh, R. G., \& Pradeepa, R. (2019). Experimental Study on Various Curing Methods of Concrete with Bagasse Ash as Supplementary Cementitious Material.

Zareei, S. A., Ameri, F., Dorostkar, F., \& Ahmadi, M. (2017). Rice husk ash as a partial replacement of cement in high strength concrete containing micro silica: Evaluating durability and mechanical properties. Case studies in construction materials, 7, 73-81.

Pacheco-Torgal, F., \& Jalali, S. (2010). Reusing ceramic wastes in concrete. Construction and Building Materials, 24(5), 832-838. 